\title{
Correction to: Introduction to the special issue on smart transportation
}

\section{Bo Xu' $\cdot$ Gautam Thakur ${ }^{2}$}

Published online: 1 July 2021

(c) Springer Science+Business Media, LLC, part of Springer Nature 2021

\section{Correction to: GeoInformatica \\ https://doi.org/10.1007/s10707-021-00432-3}

The article Introduction to the special issue on smart transportation, written by Bo Xu and Gautam Thakur, was originally published online on the publisher's internet portal on 05 March 2021 with Open Access under a Creative Commons Attribution (CC BY) license 4.0.

With the author's/authors' decision to cancel Open Access the copyright of the article changed on 04 June 2021 to (C) The Author(s), under exclusive licence to Springer Science + Business Media, LLC, part of Springer Nature 2021 with all rights reserved.

The original article has been corrected.

Publisher's note Springer Nature remains neutral with regard to jurisdictional claims in published maps and institutional affiliations.

The original article can be found online at https://doi.org/10.1007/s10707-021-00432-3.

Bo Xu

bo.5.xu@here.com

Gautam Thakur

thakurg@ornl.gov

1 HERE Technologies, Burlington, MA, USA

2 Oak Ridge National Laboratory, Oak Ridge, TN, USA 